\title{
Improvement of anaerobic digestion of sewage mixed sludge using free nitrous acid and Fenton pre-treatment
}

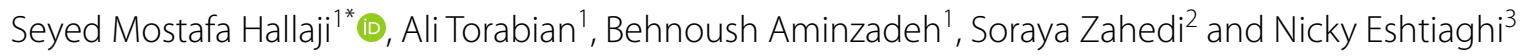

\begin{abstract}
Background: Recently, it has been indicated that free nitrous acid (FNA) and Fenton pre-treatment of waste activated sludge can enhance methane production in anaerobic digestion of waste activated sludge. In addition, it has been revealed that the substances used in these pre-treatments are both eco-friendly and economically attractive because not only are they produced in anaerobic digestion, but they are also low priced. Since primary sludge and waste activated sludge are mixed prior to anaerobic digestion in the majority of wastewater treatment plants, this study aims to assess the influence of combined FNA and Fenton on the anaerobic digestion of mixed sludge.

Results: According to this study's results, methane generation from anaerobic digestion of mixed sludge was enhanced when using FNA and Fenton pre-treatment, affirming the effectiveness of the individual and combined pre-treatments in anaerobic digestion of mixed sludge. The enhanced methane production was significant in combined pre-treatments (up to $72 \%$ ), compared with FNA and Fenton pre-treatment alone (25\% and 27\%, respectively). This corroborates the positive synergistic effect of the combined pre-treatments on methane production. The enhanced methane can be attributed to augmented soluble fractions of organic matter in addition to increased readily biodegradable organic matter, caused by the pre-treatments. Additionally, the amount of chemical oxygen demand (COD) was assessed during anaerobic digestion, and it was revealed that COD decreased considerably when the pre-treatment strategies were combined.
\end{abstract}

Conclusions: This study reveals that the pre-treatments are potentially applicable to full-scale wastewater treatment plants because a mixture of primary sludge and waste activated sludge was used for the pre-treatments. Additionally, combined FNA and Fenton pre-treatments prove more effective in enhancing methane production and organic removal than these pre-treatments alone. The enhanced methane production is important for two reasons: a higher amount of renewable energy could be generated from the enhanced methane production and the COD of digested sludge reduces in such a way that facilitates application of the sludge to agricultural lands and reduces sludge transport costs.

Keywords: Anaerobic digestion, Free nitrous acid, Fenton reagent, Methane production, Sewage sludge

\footnotetext{
*Correspondence: mostafa.hallaji69@ut.ac.ir;

seyed.mostafa.hallaji@gmail.com

${ }^{1}$ School of Environment, College of Engineering, University of Tehran,

Tehran, Iran

Full list of author information is available at the end of the article
} 


\section{Background}

Today, wastewater treatment plants play a pivotal role in protecting water streams from pollution. Activated sludge process is a conventional method for treating wastewater, mainly because of its simplicity and high efficiency in removing organic matter from wastewater [1]. However, this process produces a great volume of sludge [2]. This is an important issue because managing the produced sludge entails allocating a great deal of money that sometimes can be as high as $50 \%$ of total operating costs in wastewater treatment plants $[2,3]$. Furthermore, digestion of sludge, especially waste activated sludge, is often restricted by poor digestibility and slow fermentation process [4-6]. Consequently, adopting a pragmatic approach for addressing these issues in wastewater treatment plants is crucial.

As an influential method for dealing with sewage sludge, anaerobic digestion not only produces renewable energy from methane, but it also dispenses with aeration amenities and their related cost and energy. However, biochemical methane production of sewage sludge, particularly waste activated sludge, is limited due to lack of readily biodegradable organic matter for anaerobic organism consumption [4, 5]. To address this problem, diverse strategies have also been employed, such as chemical, mechanical, and enzymatic pre-treatment of sewage sludge prior to anaerobic digestion [7-10]. The intermediate-treatment and post-treatment of sewage sludge are also currently used strategies [11, 12]. These treatments disrupt cell walls and extracellular polymeric substance (EPS), accounting for around $70-80 \%$ of proteins and carbohydrates in sewage sludge. This provides an adequate amount of soluble organic matter for better performance of anaerobic organisms and methane production [2, 13-15]. Nevertheless, most of the mentioned methods are either eco-unfriendly or energy consuming [16].

Free nitrous acid (FNA) or $\mathrm{HNO}_{2}$ is an economically attractive, eco-friendly substance produced by nitration liquor anaerobic digestion [16]. FNA generates free radicals, such as peroxide $\left(\mathrm{H}_{2} \mathrm{O}_{2}\right)$, peroxynitrite $\left(\mathrm{ONOO}^{-}\right)$, nitrogen dioxide $\left(\mathrm{NO}_{2}\right)$, hydroxide ion $\left(\mathrm{OH}^{-}\right)$, and nitric oxide ( $\mathrm{NO}$ ) that disrupt cells and EPS, converting them to a soluble phase that is more readily biodegradable for anaerobic organisms [17, 18]. Zahedi et al. [9] indicated that 5-h exposure time to FNA pre-treatment could decrease cell viability by around $80 \%$ in waste activated sludge and enhance methane production in anaerobic digestion by $27 \%$.

Fenton reaction, as an advanced oxidation process, is formed by $\mathrm{H}_{2} \mathrm{O}_{2}$ and $\mathrm{Fe}^{+}$where $\mathrm{Fe}^{+}$functions as a catalyst for producing strong free radicals like $\mathrm{OH}^{-} \cdot$ [19]. As far as oxidation-reduction potential is concerned, the free radicals produced by Fenton reagent $(+2.33 \mathrm{~V})$ are stronger than those produced by $\mathrm{H}_{2} \mathrm{O}_{2}$ alone $(+1.36 \mathrm{~V})$ and $\mathrm{O}_{3}(+2.07 \mathrm{~V})$ [20]. Analogously, Fenton reagent disrupts cell walls and EPS, resulting in enhanced biodegradability of organic matter and methane production in anaerobic digestion of sewage sludge [21-23]. Hydrogen peroxide can also be produced by an electrochemical process in wastewater treatment plants [24]; this is of great importance because it paves the way for using Fenton pre-treatment in the anaerobic digestion process with lower costs. The Fenton reactions are demonstrated in Eqs. (1) and (2).

$$
\begin{aligned}
& \mathrm{Fe}^{2+}+\mathrm{H}_{2} \mathrm{O}_{2} \rightarrow \mathrm{Fe}^{3+}+\mathrm{HO}+\mathrm{OH}^{-} \\
& \mathrm{Fe}^{3+}+\mathrm{H}_{2} \mathrm{O}_{2} \rightarrow \mathrm{Fe}^{2+}+\mathrm{HOO}+\mathrm{H}^{+}
\end{aligned}
$$

This study investigated the influence of FNA and Fenton pre-treatments on anaerobic digestion of mixed sludge. Soluble fractions of organic matter in mixed waste activated sludge and primary sludge, before and after treatment, were measured to inspect the availability of readily biodegradable organic matter to anaerobic organisms. Furthermore, the amount of the biogas and methane production together with chemical oxygen demand (COD) were measured during anaerobic digestion to assess the effectiveness of the pre-treatments employed. To our knowledge, this is the first study evaluating the effectiveness of individual and combined FNA and Fenton pre-treatments on anaerobic digestion of mixed sludge.

\section{Results}

\section{Sludge sources}

The mixed sludge and inoculum used in this study were collected from the south wastewater treatment plant of Tehran. In this plant, primary sludge and waste activated sludge are mixed before anaerobic digestion with the ratio of 40:60 V/V. The same ratio for the mixed sludge was considered in this study.

The inoculum was collected from six mesophilic anaerobic digesters with a total capacity of $53,400 \mathrm{~m}^{3}$. Mixed sludge (primary sludge + waste activated sludge) was collected from the inlet pipe to the digesters. COD, Soluble chemical oxygen demand (SCOD), total solids (TS), total suspended solids (TSS), volatile solids (VS), and volatile suspended solids (VSS) of the inoculum and mixed sludge were measured as soon as they arrived at the university laboratory. Table 1 demonstrates the characterizations of the sludge used in this study (with standard errors achieved from triplicate measurements). 
Table 1 Characterizations of the inoculum and mixed sludge used in this study

\begin{tabular}{llllllll}
\hline Characterization & COD $(\mathbf{g} / \mathbf{L})$ & SCOD $(\mathbf{g} / \mathbf{L})$ & TS $(\mathbf{g} / \mathbf{L})$ & TSS (g/L) & VS (g/L) & VSS (g/L) & pH \\
\hline Inoculum & $38.2 \pm 0.1$ & $3.25 \pm 0.01$ & $31.6 \pm 0.3$ & $26.8 \pm 0.3$ & $25.1 \pm 0.2$ & $21.8 \pm 0.3$ & $7.65 \pm 0.01$ \\
Mixed sludge & $48.5 \pm 0.2$ & $4.25 \pm 0.02$ & $39.5 \pm 0.4$ & $35.7 \pm 0.4$ & $31.5 \pm 0.4$ & $29.1 \pm 0.2$ & $6.32 \pm 0.02$ \\
\hline
\end{tabular}

Table 2 Designated concentrations for pre-treatments

\begin{tabular}{lllll}
\hline Pre-treatments & $\begin{array}{l}\text { FNA (mg } \\
\text { FNA/L) }\end{array}$ & $\begin{array}{l}\mathbf{H}_{\mathbf{2}} \mathbf{O}_{\mathbf{2}} \text { (mg } \\
\left.\mathbf{H}_{\mathbf{2}} \mathbf{O}_{\mathbf{2}} \mathbf{\text { g VS}}\right)\end{array}$ & $\begin{array}{l}\mathrm{Fe}^{+} \mathbf{~ m g ~ F e} \\
\mathbf{m} \mathbf{~ H ~ H}_{\mathbf{2}} \mathbf{O}_{\mathbf{2}}\end{array}$ & $\mathbf{p H}$ \\
\hline control & 0 & 0 & 0 & 6.32 \\
FNA & 2.5 & 0 & 0 & 5.5 \\
Fenton 1 & 0 & 2.5 & 0.0067 & 3 \\
Fenton 2 & 0 & 5 & 0.0067 & 3 \\
FNA + Fenton 1 & 2.5 & 2.5 & 0.0067 & 5.5 and 3 \\
FNA + Fenton 2 & 2.5 & 5 & 0.0067 & 5.5 and 3 \\
\hline
\end{tabular}

\section{Pre-treatment constituents}

In this study, FNA pre-treatment, Fenton pre-treatment and combination of FNA and Fenton pre-treatment of mixed sludge were implemented prior to anaerobic digestion process. The designated concentrations of the substances used in these pre-treatments are shown in Table 2.

\section{Solubilisation of organic matter}

The influence of different pre-treatments on the substrate's SCOD was assessed prior to biochemical methane potential tests. It was shown that the amount of SCOD increased dramatically in all pre-treated reactors (Fig. 1). The highest SCOD (17.75 g SCOD/L) was achieved in the BMP reactor treated by FNA + Fenton2. This was considerably higher than those obtained from FNA and Fenton pre-treated bioreactors alone. Comparing the effect of the individual pre-treatments, Fenton2 alone caused a considerably higher SCOD (15.5 g SCOD/L) than its FNA counterpart (10.34 g SCOD/L), suggesting a higher effectiveness of Fenton pre-treatment than FNA.

Since not all types of organic matter are biodegradable for the anaerobic organisms, soluble fractions of protein and polysaccharide, the two important constituents of SCOD, were measured before and after treatments. Proteins and polysaccharides account for around $60 \%$ of the organisms' constituents [19]. Thus, enhancement of soluble fractions of protein and polysaccharide after pretreatments could affirm that more readily biodegradable organic matter is provided for anaerobic organisms due to disruption of cell walls and EPS in the substrate. The amounts of soluble protein and polysaccharide before and after treatments were measured in control and pretreatment reactors (Figs. 2, 3). As the most significant augmentation, FNA + Fenton2 pre-treatment increased the amount of soluble proteins from $0.27 \mathrm{~g}$ protein/L to $2.9 \mathrm{~g}$ protein/L. The influence of Fenton 2 and FNA + Fenton1 on solubalisation of proteins was identical that both increased soluble protein to $2.5 \mathrm{~g}$ protein/L. Most pretreatments increased the soluble polysaccharide fraction by around 30\%; however, the FNA pre-treatment increased the soluble polysaccharide fraction by $19 \%$.

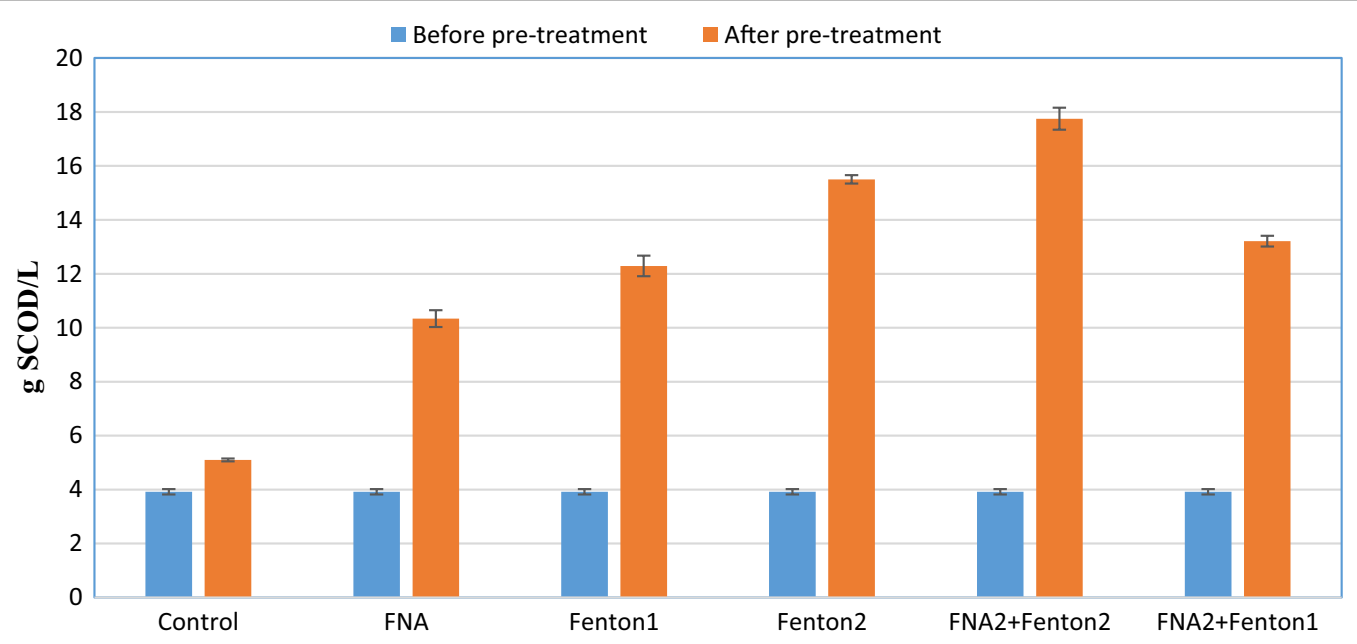

Fig. 1 The amount of SCOD before and after pre-treatment. Error bars represent standard error achieved from triplicate tests 


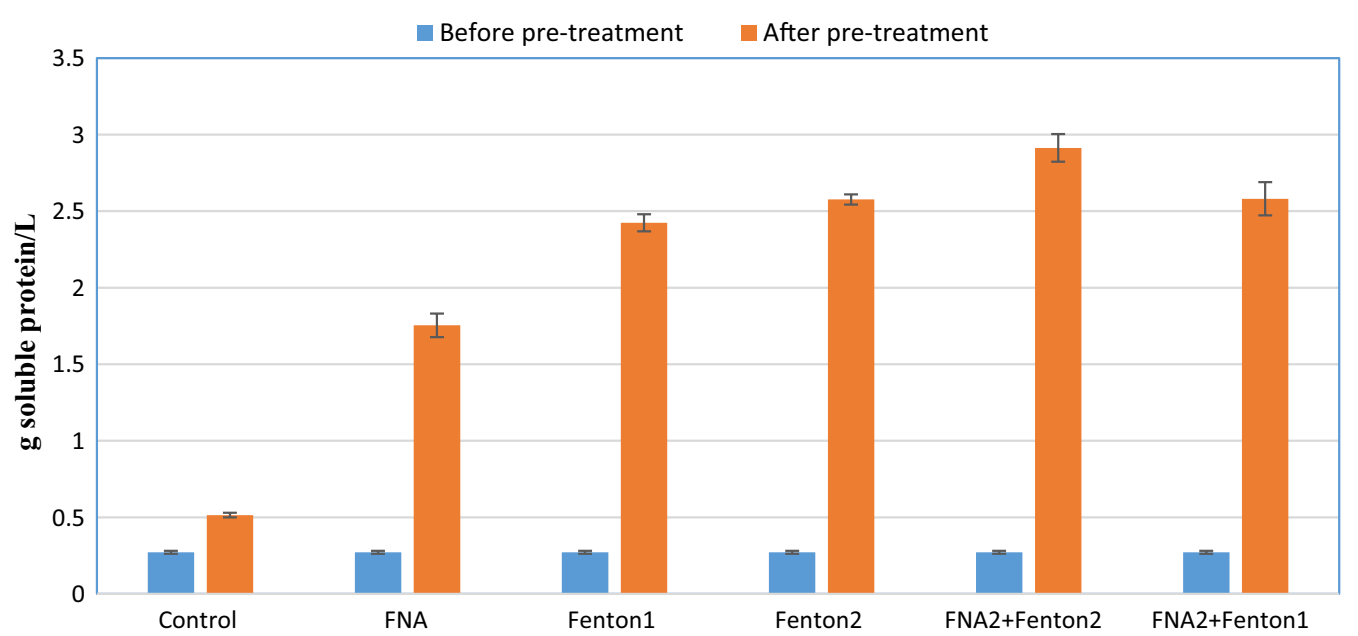

Fig. 2 The amount of soluble protein before and pre-treatment. Error bars represent standard error achieved from triplicate tests

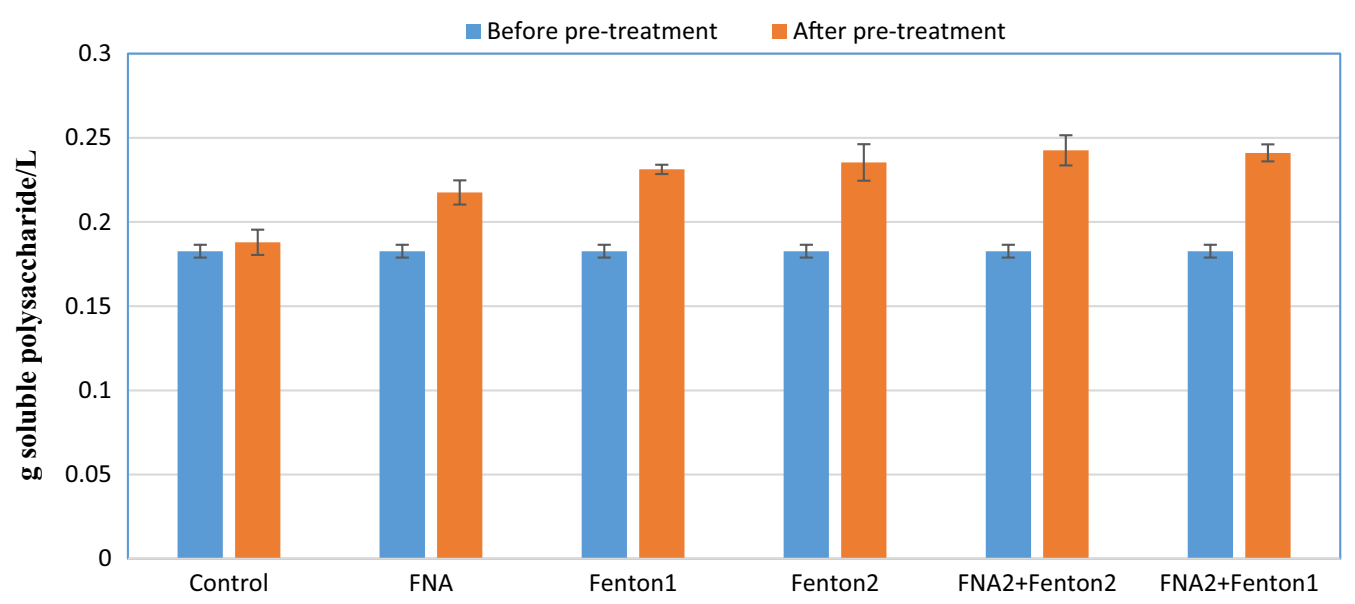

Fig. 3 The amount of soluble polysaccharide before and after pre-treatment. Error bars represent standard error achieved from triplicate tests

\section{Daily biogas production}

Daily biogas generation from different bioreactors was measured during the anaerobic digestion process. The total volume of biogas produced from the pretreated bioreactors was significantly enhanced in comparison to the control bioreactor (Figs. 4 and 5). However, during the first 5 days of the digestion process, the volume of biogas produced from the pre-treated rectors was slightly lower than that of the control, and it gradually overtook the volume of the control after 5 days. This is in agreement with previous studies in which a slight delay in biogas yield from pre-treated bioreactors was observed $[18,25,26]$. This is likely due to slight inhibitory effect on anaerobic organisms' activity, which is produced by low nitrite/FNA concentration and probably also by overloading the pre-treated reactors with soluble organic matter that could produce a delay in the biogas production [27]. Therefore, although the maximum daily biogas production was obtained from the control bioreactor $(970 \mathrm{~mL}$ in day 3), but the surface area below each chart, which represents the cumulative biogas production, was significantly higher in pre-treated reactors than that of the control at the end of the digestion. Accordingly, the FNA + Fenton2 pre-treated bioreactor achieved the highest volume of cumulative biogas production. This was also significantly higher than cumulative biogas from FNA and Fenton pre-treatment alone $(p<0.05)$.

\section{Cumulative methane production}

The amount of cumulative methane production from anaerobic digestion of mixed sludge was regularly measured during the anaerobic digestion. Analogous to biogas production, the amount of methane production 


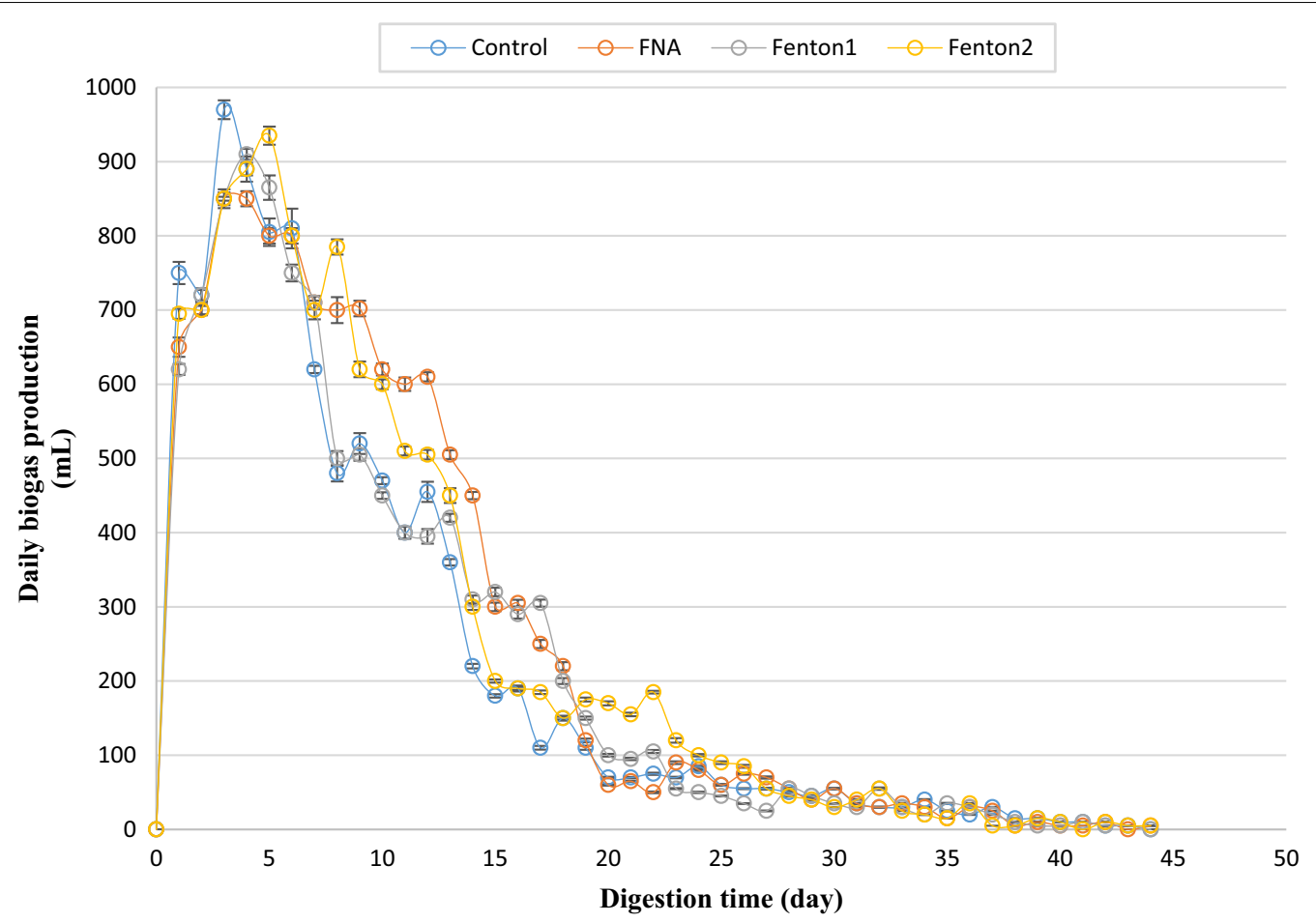

Fig. 4 Daily biogas production from individual pre-treated bioreactors. Error bars represent standard error obtained from triplicate measurements

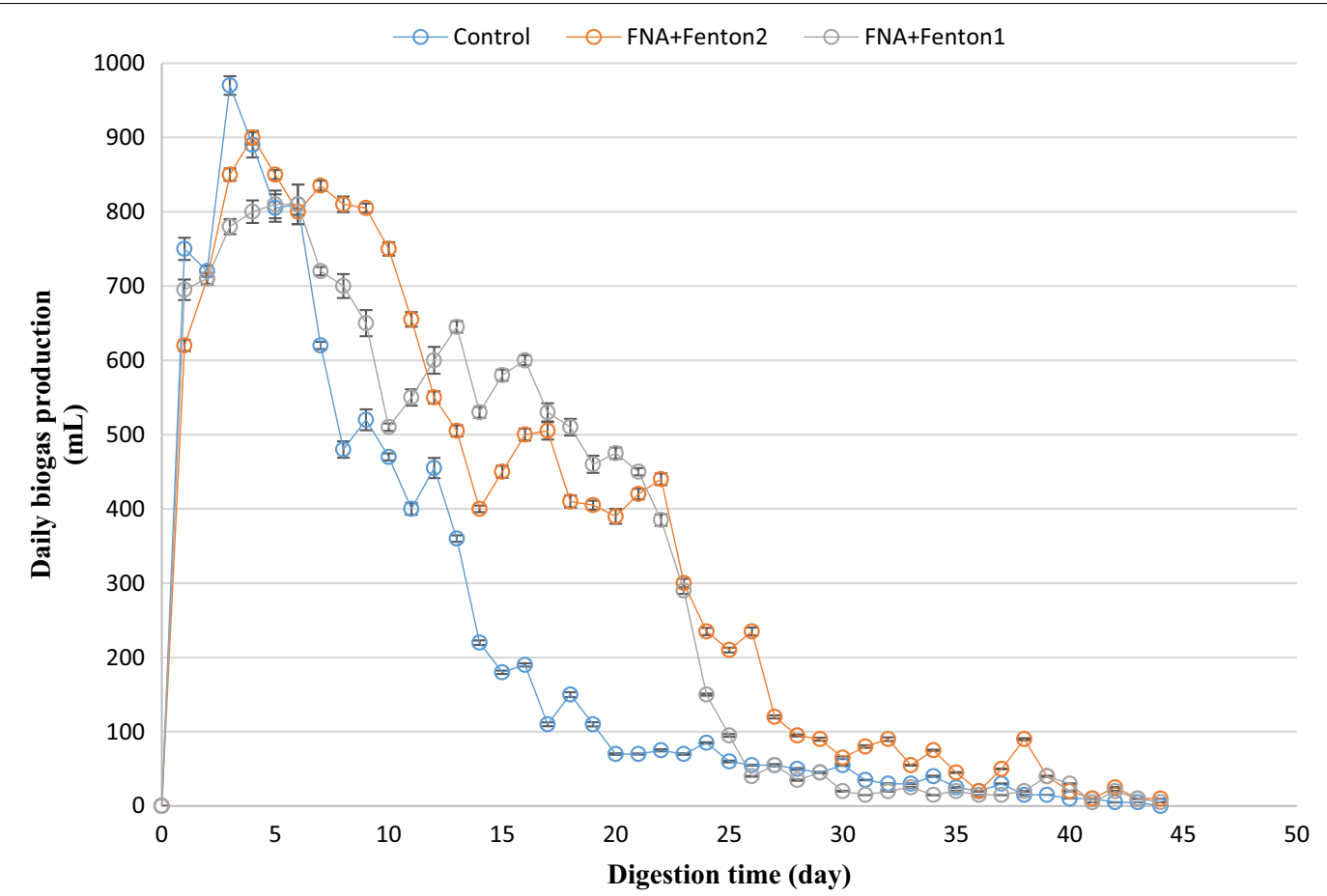

Fig. 5 Daily biogas production from combined pre-treated bioreactors. Error bars represent standard error obtained from triplicate measurements 
in the first 5 days of the digestion was slightly lower than that of the control reactor. However, the amount of methane production overtook that of the control gradually (Figs. 6 and 7). The considerably enhanced methane production from the pre-treated biochemical methane potential reactors could be attributed to the increased readily biodegradable organic matter that was available to anaerobic organisms due to disruption of cell walls. The highest cumulative methane production was obtained from combined FNA and Fenton pre-treated reactors. Accordingly, the amount of cumulative methane production from the biochemical methane potential reactor, pretreated with FNA + Fenton2 increased by $72 \%$ compared to the control. This was significantly higher than methane improvement obtained from these pre-treatments alone $(p<0.05)$, affirming the synergistic effect of combined FNA and Fenton pre-treatment. Followed by that, FNA + Fenton 1 and Fenton2 pre-treatments caused the highest methane production, respectively, with $333 \mathrm{~mL} \mathrm{CH}_{4} / \mathrm{g}$ vs. and $267 \mathrm{~mL} \mathrm{CH}_{4} / \mathrm{g}$ vs. The methane/biogas yield fluctuated between 50 and $60 \%$ during the anaerobic digestion process, revealing that the enhanced cumulative methane production was mainly due to the enhanced biogas production and biodegradability of organic matter, not due to the enhanced methane content of the biogas. Analogously, the carbon dioxide/biogas yield did not experience a considerable change during the anaerobic digestion process (it fluctuated between 25 and 35\%).

\section{COD removal efficiency}

The amount of COD in biochemical methane potential reactors was measured during the anaerobic digestion process. The amount of COD removal in the pre-treated reactors was considerably enhanced compared to the control reactor (Figs. 8 and 9). This could justify the higher methane and biogas production achieved in the pre-treated reactors. The highest COD removal efficiency was obtained by the FNA + Fenton 2 pre-treated reactor, in which COD was significantly reduced by $59 \%$, compared to the control ( $34 \%$ reduction) $(p<0.05)$. The other combined pre-treatment (FNA + Fenton1) caused the second highest COD removal of 54\%. Furthermore, FNA pre-treatment was approximately as efficient as Fenton pre-treatment in removing COD with $43 \%$, compared with $40 \%$ and $44 \%$ obtained by Fenton 1 and Fenton2, respectively.

\section{Discussion}

Having taken all aspects into account, the pre-treatments clearly increased the soluble fraction of organic matter. This stems mainly from oxidative properties of the pretreatments employed in this study that disrupt cell walls and EPS $[17,19]$. More organic matter was solubilized

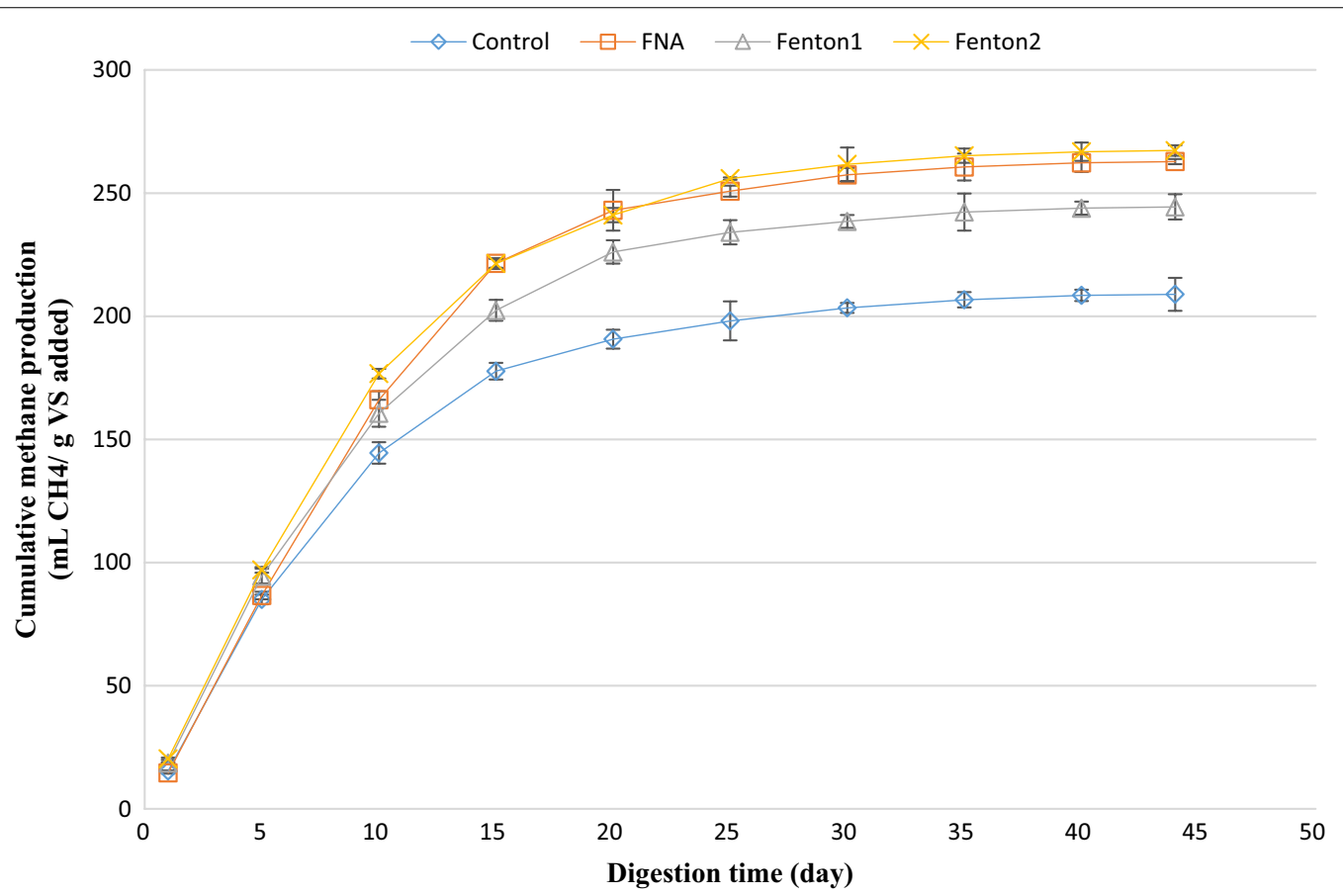

Fig. 6 Cumulative methane production from singular pre-treated bioreactors. Error bars represent standard error obtained from triplicate measurements 


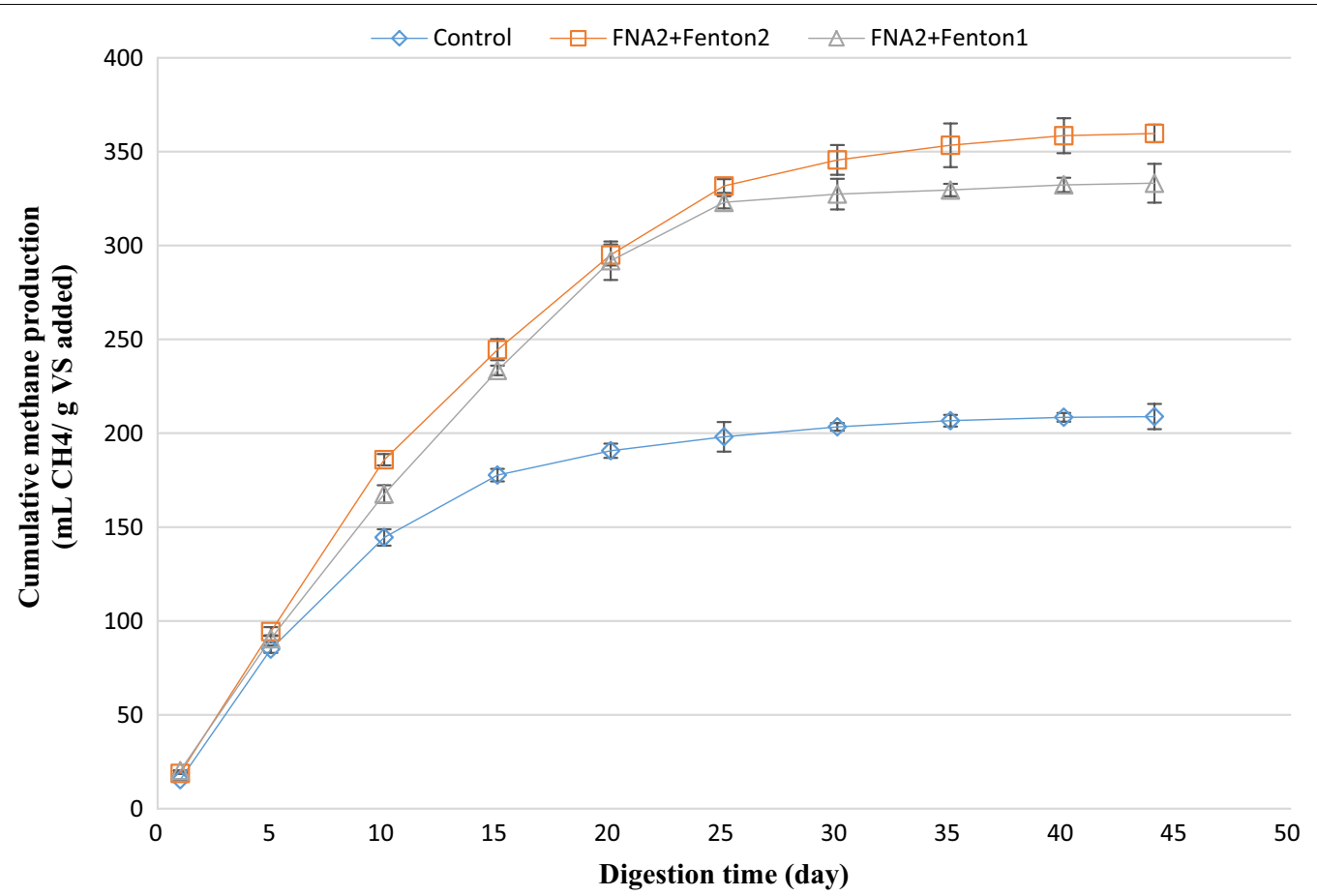

Fig. 7 Cumulative methane production from combined pre-treated bioreactors. Error bars represent standard error obtained from triplicate measurements

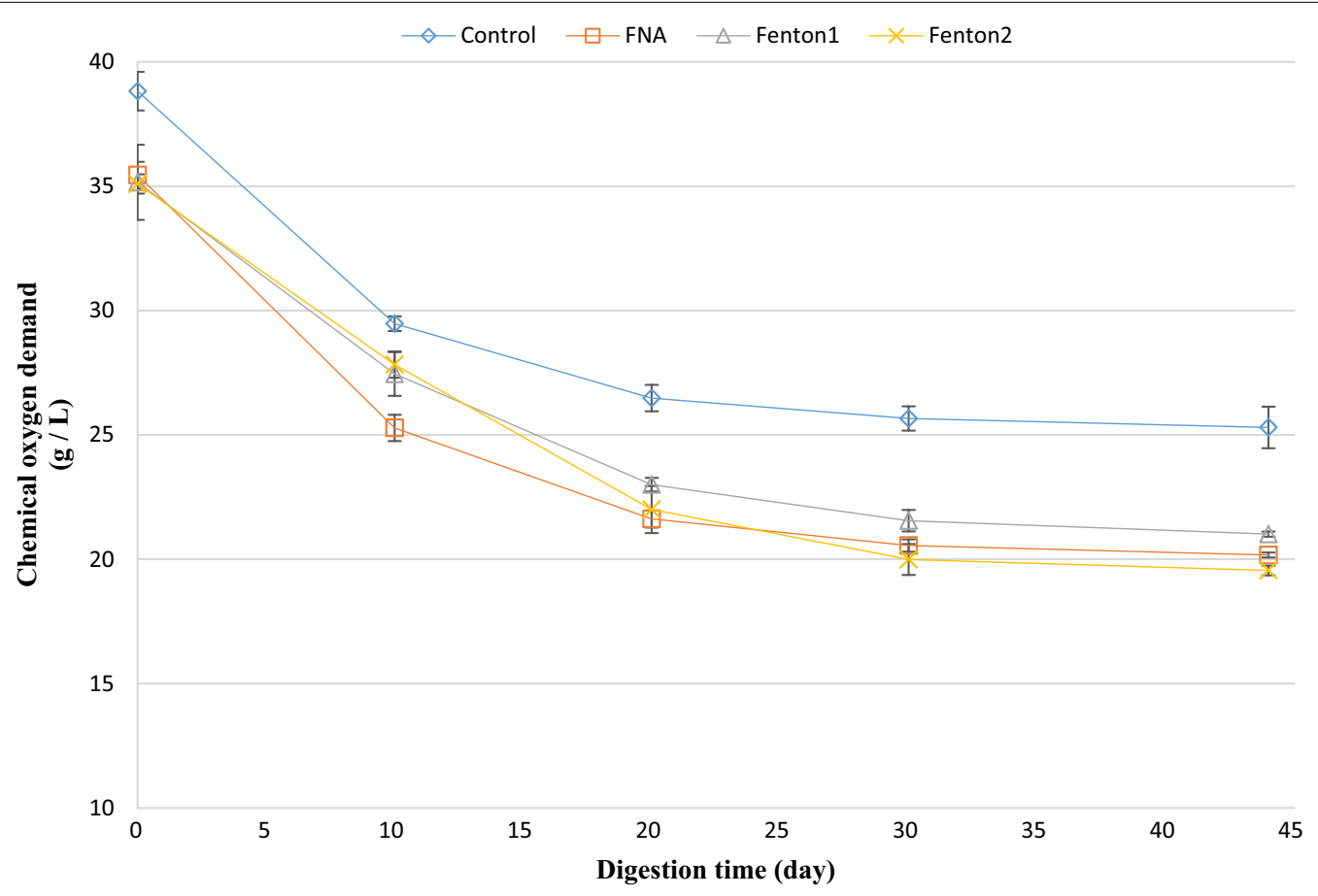

Fig. 8 COD trend in singular pre-treated bioreactors. Error bars represent standard error obtained from triplicate measurements 


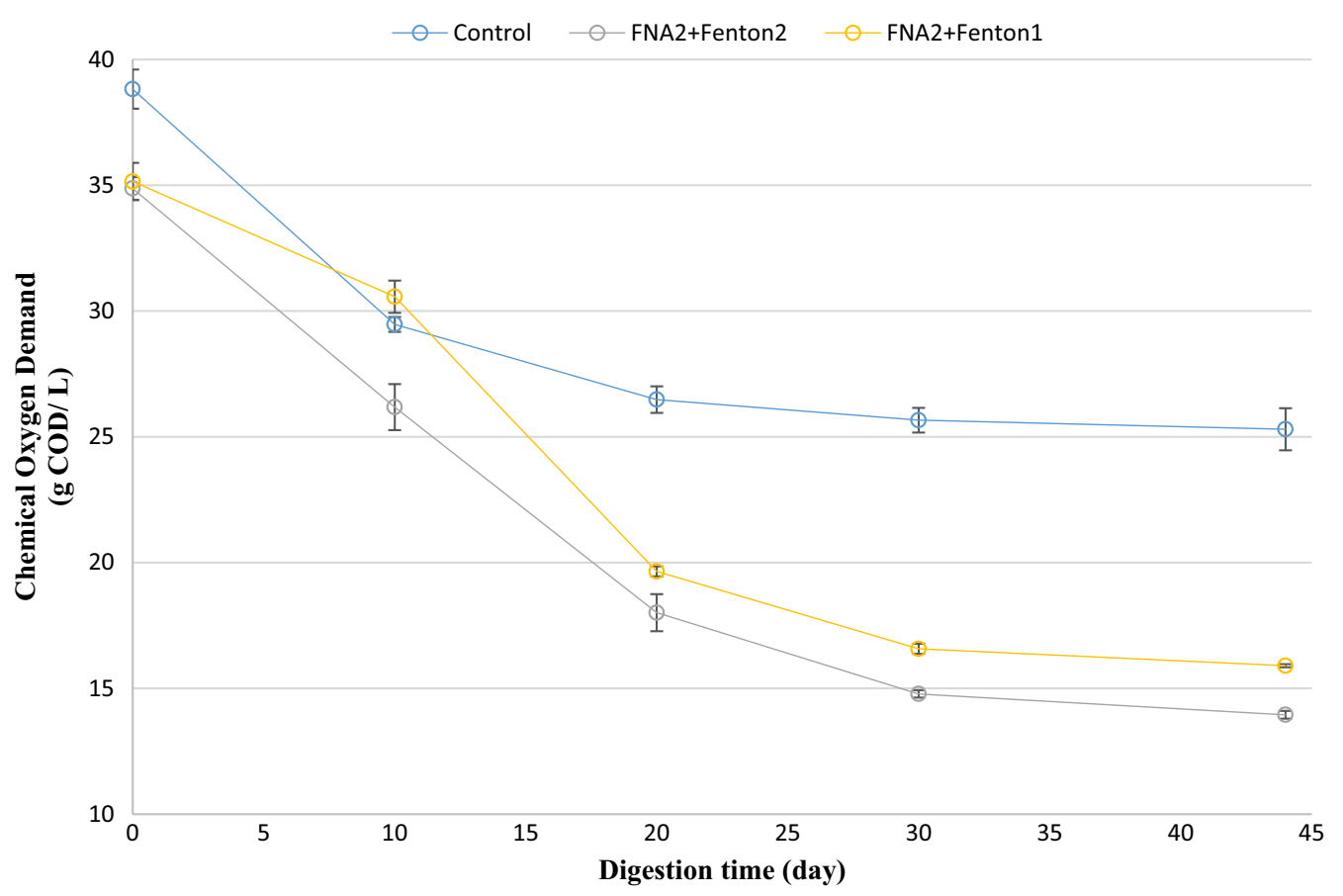

Fig. 9 COD trend in combined pre-treated bioreactors. Error bars represent standard error obtained from triplicate measurements

when higher concentrations of pre-treatment reagents were used. When it comes to effectiveness of the pretreatments in solubilizing different types of organic matter, the pre-treatments were much more influential in solubilizing protein than polysaccharide. This can be attributed to biocidal effect of the pre-treatments that affect proteins more substantially than polysaccharide [9], as the main composition of organisms' cell is around $50 \%$ protein [19]. The amount of soluble fraction of organic matter is enhanced slightly in the control reactor after pre-treatment time, suggesting some solubalisation with no chemical additives and $\mathrm{pH}$ control. The improvement of organic solubalisation is consistent with but slightly higher than the results achieved in previous studies, in which soluble fraction of organic matter was analogously augmented $[9,18,25,28-30]$. This can be attributed to sludge characteristics and the concentration of the substances used in this study.

Whether alone or combined, FNA and Fenton pretreatments enhanced methane production, affirming effectiveness of these pre-treatments in improving methane production from anaerobic digestion process. The methane enhancement was mainly because of augmented biogas production, not because of considerably enhanced methane content, due to the approximately constant methane/biogas yield. This stems from the release of more readily biodegradable organic matter in pre-treated bioreactors (Figs. 1, 2, 3). The higher concentrations of the pre-treatment constituents resulted in enhanced biogas production attributable to providing more soluble organic matter for anaerobic organisms. Combined pre-treatments achieved significantly higher methane production than FNA and Fenton pre-treatments alone $(p<0.05)$, indicating a positive synergistic effect of these pre-treatments on methane production. This could be because the free radicals released by each pre-treatment hydrolyze different types of organic matter in the substrate that resulted in enhanced biodegradability of organic matter and methane production in biochemical methane potential reactors. In all biochemical methane potential tests, a short period of lag time (5 days) was observed during which biogas production from pretreated reactors gradually overtook that of the control. This could be attributed to low nitrite/FNA concentration and probably also to overloading the pre-treated reactors with soluble organic matter. From an economic and environmental perspective, the enhancement of methane production is of great significance because not only could higher renewable energy be generated, but also methane emission into the atmosphere as a major greenhouse gas could be decreased from anaerobic digestion of sewage sludge [31]. The amount of methane enhancement caused by individual FNA pre-treatment was $27 \%$ in Zahedi et al. [9] and 20\% in Wang et al. [28]. In this study, a similar amount of methane enhancement was achieved (25\%) from an individual FNA pre-treated bioreactor. The 
difference can be mainly attributed to the different digestion time, characterizations of the substrate and the inoculum employed in this study. The amount of methane enhancement caused by singular Fenton pre-treatment was 19.4\% in Erden and Filibeli [23] and 15\% in Pilli et al. [31]. A slightly higher amount of methane enhancement was achieved in this study with singular Fenton pre-treatment $(27 \%)$, which further corroborate the effectiveness of Fenton pre-treatment in enhancing methane production from anaerobic digestion of the sewage sludge. Compared to combined FNA and thermal pre-treatment used in Wang et al. [28], the amount of maximum cumulative methane production was about $30 \%$ higher in this study. However, different sludge specifications and using higher dosages of FNA should be considered for more precise comparison.

The COD of digested sludge is one of the most important characteristics in applying the sludge to agricultural lands and forests. The amount of COD removal improved considerably in the biochemical methane potential reactors treated with FNA and Fenton. The improved COD is linked to higher biogas and methane production in the biochemical methane potential reactors because producing higher methane (in relatively constant methane/ biogas yield) implies that higher amounts of organic matter have been consumed by anaerobic organisms, resulting in lower COD at the end of the digestion process. The enhanced COD removal in this study is of paramount importance because it lowers the amount of sludge and reduces the associated costs of transport. It also paves the way for shaping an integrated, sustainable system for treating sewage sludge by applying sludge to agricultural lands and forests.

Despite the significant results this research represents, applying new systems to anaerobic digestion of sewage sludge entails a great deal of money and time. Therefore, in future studies, a precise economic assessment for fullscale application of combined FNA and Fenton pre-treatments seems indispensable. Additionally, the influence of the pre-treatments on the microbial community should be put into perspective to provide deep insight into the mechanism of these pre-treatments and possible longterm side-effects on microbial behaviour.

\section{Conclusions}

This study investigated the feasibility of enhancing anaerobic digestion of mixed primary sludge and waste activated sludge through combined FNA and Fenton pretreatment. Combined FNA and Fenton pre-treatments were shown to increase soluble fractions of organic matter considerably more than these pre-treatments alone, resulting in enhanced biodegradability of organic matter, biogas production, methane production, and COD removal during the anaerobic digestion process. The improved methane production is of paramount importance, not only because higher amounts of renewable energy are obtained from the anaerobic digestion process, but also because lower methane emission, a major greenhouse gas, is released to the atmosphere. The improved COD of the digested sludge paves the way for having a more integrated and sustainable sludge treatment process, as sludge transport expenditures are reduced and the digested sludge achieves a higher potential application to agricultural lands. Additionally, combined FNA and Fenton pre-treatment is potentially an economically attractive and environmentally friendly technology, particularly considering that both are obtainable as by-products from anaerobic digestion of sewage sludge.

\section{Methods}

Analytical methods

COD, SCOD, VS, VSS, TS, and TSS were measured according to standard methods for the examination of water and wastewater [32]. Biopolymers (proteins and polysaccharides) were measured in the soluble phase before and after pre-treatment. To separate solids from liquids, sludge was centrifuged for $30 \mathrm{~min}$ at $10,000 \mathrm{rpm}$ and the supernatant was filtrated through a $0.45 \mu \mathrm{m}$ pore size glass fiber filter. Proteins were measured with the Folin Phenol Reagent according to Lowry [33] and Peterson [34]. Phenol with sulfuric acid was also used for measuring polysaccharide [35]. These methods have been widely used to determine the proteins and polysaccharides concentration, even in sludge pre-treatment studies to determine the effect of pre-treatments on sludge properties $[9,13,25,26,36,37]$.

The volume of biogas was measured by liquid displacement method [38]. The liquid barrier used in this method was $100 \%$ saturated with $\mathrm{NaCl}$ and acidified with $\mathrm{H}_{2} \mathrm{SO}_{4}(\mathrm{pH}=2)$ to reduce dissolution of the biogas (specially $\mathrm{CO}_{2}$ and $\mathrm{CH}_{4}$ ) in the liquid barrier and eliminate the errors in measuring the volume of biogas [38]. Gas chromatography (GC) with a thermal conductivity detector (TCD) at $100{ }^{\circ} \mathrm{C}$ and helium as a carrier gas was employed when analyzing the main biogas composition $\left(\mathrm{CH}_{4}\right.$ and $\left.\mathrm{CO}_{2}\right)$. The biogas was collected from the bioreactors in Tedlar gas bags before using in GC measurements.

\section{FNA and Fenton methodology}

One-liter reactors were used when carrying out FNA pretreatment. FNA concentration used in this study was calculated by the equations $[\mathrm{FNA}]=\left[\mathrm{NaNO}_{2}\right] /\left[\mathrm{Ka} \times 10^{\mathrm{pH}}\right]$ and $\mathrm{Ka}=e^{-2300 /\left(273+{ }^{\circ} \mathrm{C}\right)}$ [39]. In these equations, ${ }^{\circ} \mathrm{C}$ is the room temperature $\left(\approx 25{ }^{\circ} \mathrm{C}\right)$, $\mathrm{pH}$ equals 5.5 , and $\mathrm{NaNO}_{2}$ is the concentration of nitrite salt. The considered 
FNA concentration is obtained from economic assessments from literature review [18, 40-42]. With the FNA concentration, the nitrite salt concentration can be calculated. In this experiment, the $\mathrm{pH}$ of the mixed sludge was set at $5.5 \pm 0.1$ with $1 \mathrm{M} \mathrm{HCL}$. Next, the calculated nitrite salt concentration was added to the treatment reactors, and the mixture was gently blended with a magnetic stirrer for $5 \mathrm{~h}$ [25].

Fenton pre-treatments were also conducted in 1-L reactors. The designated concentrations of $\mathrm{H}_{2} \mathrm{O}_{2}$ for the Fenton reaction were considered from the literature review [19, 23, 30, 31]. First, the $\mathrm{pH}$ of the mixed sludge was set to three by $\mathrm{H}_{2} \mathrm{SO}_{4}$ [22]. The designated $\mathrm{Fe}^{+}$and $\mathrm{H}_{2} \mathrm{O}_{2}$ concentrations were then achieved by adding $\mathrm{FeSO}_{4}$ and $\mathrm{H}_{2} \mathrm{O}_{2}$ to the reactors, and the pre-treatment lasted for $1 \mathrm{~h}$ to obtain maximum solubalisation and biodegradability of organic matter, according to Pham et al. [43]. In the Fenton reaction, the ratio between $\mathrm{H}_{2} \mathrm{O}_{2}$ and $\mathrm{Fe}^{2+}$ was set at 0.0067 , according to Erden and Filibeli [30] and Pham et al. [43].

For combined pre-treatments, the FNA pre-treatment was first conducted, and after 5-h exposure time, the Fenton pre-treatment with 1 -h exposure time was conducted. To keep the $\mathrm{pH}$ of the reactors stable, the $\mathrm{pH}$ was regularly measured during the treatment process. During FNA pre-treatment, the $\mathrm{pH}$ of the mixture remained stable at 5.5 , but the $\mathrm{pH}$ in the Fenton pre-treatment tended to fluctuate so that it was set at three again once it changed.

\section{Biochemical methane potential tests}

For the biochemical methane potential tests, 18 bioreactors with $1000 \mathrm{~mL}$ capacity were considered with $500 \mathrm{~mL}$ working volume. Biochemical methane potential system is shown in Fig. 10. The ratio between inoculum and mixed sludge was 2 for proper performance of bioreactors, according to Boulanger et al. [44]. A control test (mixed sludge without chemical additives and $\mathrm{pH}$ control) was also conducted. Prior to mixing with the inoculum, the $\mathrm{pH}$ of the pre-treated mixed sludge increased to seven and maintained at $37 \pm 1{ }^{\circ} \mathrm{C}$ to prevent $\mathrm{pH}$ and temperature shock to anaerobic organisms of the inoculum. After mixing the substrate and inoculum, the reactors were completely sealed to provide a strict anaerobic environment for better performance of anaerobic organisms. The reactors were put into a warm water bath heated by automatic heaters, and the temperature was set at $37 \pm 1{ }^{\circ} \mathrm{C}$. To provide uniform temperature and substrate distribution for better organism activity, the reactors were permanently mixed $(100 \mathrm{rpm})$ by magnetic stirrers during the digestion process. The measurements were performed regularly for 44 days, when no biogas

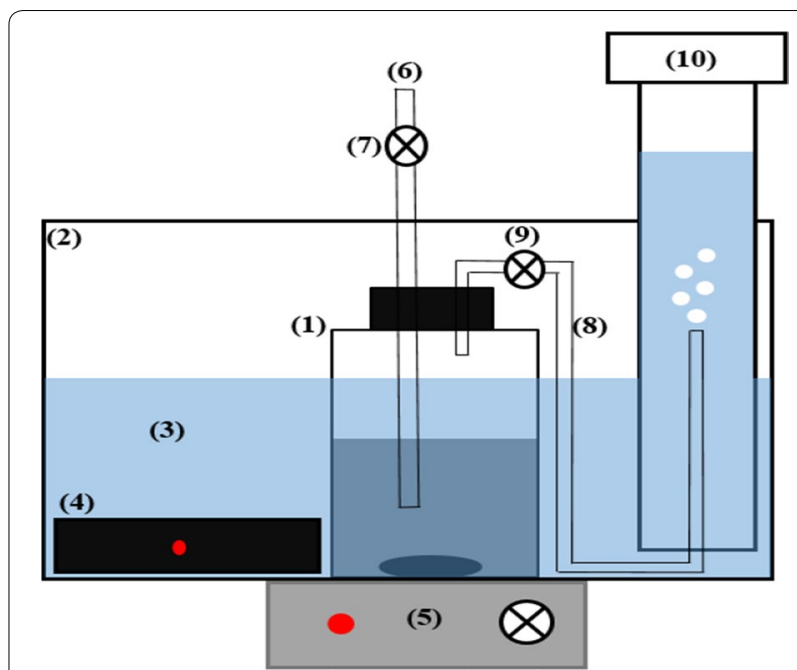

Fig. 10 Schematic of experimental system. (1) Biochemical methane potential reactor, (2) aquarium, (3) saturated and acidified water, (4) automatic heater, (5) magnetic stirrer, (6) sampling pipe, (7) sampling control valve, (8) biogas collecting pipe, (9) biogas control valve, (10) graduated cylinder

production was detected from the bioreactors (Additional file 1).

For assessing the influence of nitrite on inoculum performance, two sets of blanks were considered. Blank $\mathrm{I}$, in which inoculum without chemical additives and substrate was used in biochemical methane potential tests. Blank II, identical to blank I except with the addition of nitrite stock solution, which resulted in an initial nitrite level of around $70 \mathrm{mg} \mathrm{N}-\mathrm{NO}_{2}-/ \mathrm{L}$. Assessing bioreactors I and II, it was shown that the concentration of nitrite used in this study has no a significant effect on inoculum performance. This is in agreement with previous studies, in which no significant influences on inoculum performance were analogously observed $[9,18,26,28]$. The methane production from mixed sludge was obtained by subtracting measured biogas production in an experimental bioreactor from that measured in blank I.

\section{Data analyses}

To determine the significance of differences in the parameters studied, one-way factor Analysis of Variance ANOVA was used with significance levels of $p<0.05$. Data analysis and graph processing were carried out with Microsoft Excel software (2010).

\section{Additional file}

Additional file 1. Additional tables and figures. 


\section{Abbreviations}

COD: chemical oxygen demand; SCOD: soluble chemical oxygen demand; TS: total solid; TSS: total suspended solid; VS: volatile solid; VSS: volatile suspended solid; GC: gas chromatography; TCD: thermal conductivity detector; FNA: free nitrous acid; EPS: extra-cellular polymeric substance.

\section{Authors' contributions}

SMH reviewed literatures and chose the subject with BA and AT guidance. SMH designed and provided the BMP systems. AT and BA guided SMH for better design and probable drawbacks. SZ guided SMH for carrying out free nitrous acid pre-treatments and suggested new ideas in this scope. SMH and BA conducted experiments. SMH, BA and AT wrote the paper. NE proofed data and text and gave guidance for formatting and submission of the paper. All authors read and approved the final manuscript.

\section{Author details}

'School of Environment, College of Engineering, University of Tehran, Tehran, Iran. ${ }^{2}$ Catalan Institute for Water Research (ICRA), Girona, Spain. ${ }^{3}$ School of Engineering, Chemical and Environmental Engineering, RMIT University, Melbourne, Australia.

\section{Acknowledgements}

The authors acknowledge the Tehran Sewerage Company for supporting this study financially and sending required information and sludge to the University of Tehran

\section{Competing interests}

The authors declare that they have no competing interests.

\section{Availability of data and materials}

All data generated during this study are included in this published article and its additional file.

\section{Consent for publication}

Not applicable.

\section{Ethics approval and consent to participate}

Not applicable.

\section{Funding}

Tehran Sewerage Company carried out the task of supporting financially this study for experimental analyses.

\section{Publisher's Note}

Springer Nature remains neutral with regard to jurisdictional claims in published maps and institutional affiliations.

Received: 9 June 2018 Accepted: 22 August 2018

Published online: 28 August 2018

\section{References}

1. Nazari L, Yuan Z, Santoro D, Sarathy S, Ho D, Batstone D, et al. Low-temperature thermal pre-treatment of municipal wastewater sludge: process optimization and effects on solubilization and anaerobic degradation. Water Res. 2017:113:111-23.

2. Neyens E, Baeyens J, Dewil R, De Heyder B. Advanced sludge treatment affects extracellular polymeric substances to improve activated sludge dewatering. J Hazard Mater. 2004;106:83-92.

3. Appels L, Degrève J, Van der Bruggen B, Van Impe J, Dewil R. Influence of low temperature thermal pre-treatment on sludge solubilisation, heavy metal release and anaerobic digestion. Bioresour Technol. 2010;101:5743-8.

4. Tiehm A, Nickel K, Zellhorn M, Neis U, Tiehm A. Ultrasonic waste activated sludge disintegration for improving anaerobic stabilization. Water Res. 2001;35:2003-9.

5. Sanscartier D, MacLean HL, Saville B. Electricity production from anaerobic digestion of household organic waste in Ontario: techno-economic and GHG emission analyses. Environ Sci Technol. 2012;46(2):1233-42.
6. Appels L, Baeyens J, Degrève J, Dewil R. Principles and potential of the anaerobic digestion of waste-activated sludge. Prog Energy Combust Sci. 2008;34:755-81.

7. Ennouri H, Miladi B, Diaz SZ, Güelfo LAF, Solera R, Hamdi M, et al. Effect of thermal pretreatment on the biogas production and microbial communities balance during anaerobic digestion of urban and industrial waste activated sludge. Bioresour Technol. 2016;214:184-91.

8. Zhang D, Chen Y, Zhao Y, Ye Z. A new process for efficiently producing methane from waste activated sludge: alkaline pretreatment of sludge followed by treatment of fermentation liquid in an EGSB reactor. Environ Sci Technol. 2011;45:803-8.

9. Zahedi S, Icaran P, Yuan Z, Pijuan M. Enhancing sludge biodegradability through free nitrous acid pre-treatment at low exposure time. Chem Eng J. 2017;321:139-45

10. Sólyom K, Mato RB, Pérez-Elvira SI, Cocero MJ. The influence of the energy absorbed from microwave pretreatment on biogas production from secondary wastewater sludge. Bioresour Technol. 2011;102:10849-54.

11. Campo G, Cerutti A, Zanetti M, Scibilia G, Lorenzi E, Ruffino B. Enhancement of waste activated sludge (WAS) anaerobic digestion by means of pre-and intermediate treatments. Technical and economic analysis at a full-scale WWTP. J Environ Manage. 2017;216:372-82.

12. Svensson K, Kjørlaug O, Higgins MJ, Linjordet R, Horn SJ. Post-anaerobic digestion thermal hydrolysis of sewage sludge and food waste: effect on methane yields, dewaterability and solids reduction. Water Res. 2018;132:158-66.

13. Ma B, Peng Y, Wei Y, Li B, Bao P, Wang Y. Free nitrous acid pretreatment of wasted activated sludge to exploit internal carbon source for enhanced denitrification. Bioresour Technol. 2015;179:20-5.

14. Carrère $H$, Dumas $C$, Battimelli $A$, Batstone DJ, Delgenès JP, Steyer JP, et al. Pretreatment methods to improve sludge anaerobic degradability: a review. J Hazard Mater. 2010;183:1-15.

15. Foladori P, Bruni L, Tamburini S, Ziglio G. Direct quantification of bacterial biomass in influent, effluent and activated sludge of wastewater treatment plants by using flow cytometry. Water Res. 2010;44:3807-18.

16. Law Y, Ye L, Wang Q, Hu S, Pijuan M, Yuan Z. Producing free nitrous acid-A green and renewable biocidal agent-from anaerobic digester liquor. Chem Eng J. 2015;259:62-9.

17. Pijuan $M$, Wang $Q$, Ye L, Yuan Z. Improving secondary sludge biodegradability using free nitrous acid treatment. Bioresour Technol. 2012;116:92-8.

18. Wang $Q$, Ye L, Jiang G, Jensen PD, Batstone DJ, Yuan Z. Free nitrous acid (FNA)-based pretreatment enhances methane production from waste activated sludge. Environ Sci Technol. 2013:47:11897-904.

19. Pilli S, Yan S, Tyagi RD, Surampalli RY. Overview of Fenton pre-treatment of sludge aiming to enhance anaerobic digestion. Rev Environ Sci Biotechnol. 2015;14:453-72.

20. Carballa M, Duran C, Hospido A. Should we pretreat solid waste prior to anaerobic digestion? An assessment of its environmental cost. Environ Sci Technol. 2011;45:10306-14.

21. Frølund B, Palmgren R, Keiding K, Nielsen PH. Extraction of extracellular polymers from activated sludge using a cation exchange resin. Water Res. 1996:30:1749-58

22. Neyens E, Baeyens J. A review of classic Fenton's peroxidation as an advanced oxidation technique. Mater: J Hazard; 2003.

23. Erden G, Filibeli A. Effects of Fenton pre-treatment on waste activated sludge properties. Clean Soil Air Water. 2011:39:626-32.

24. Rozendal RA, Leone E, Keller J, Rabaey K. Efficient hydrogen peroxide generation from organic matter in a bioelectrochemical system. Electrochem Commun. 2009;11(9):1752-5.

25. Zahedi S, Icaran P, Yuan Z, Pijuan M. Assessment of free nitrous acid pre-treatment on a mixture of primary sludge and waste activated sludge: effect of exposure time and concentration. Bioresour Technol. 2016;216:870-5.

26. Zahedi S, Icaran P, Yuan Z, Pijuan M. Effect of free nitrous acid pretreatment on primary sludge at low exposure times. Bioresour Technol. 2017;228:272-8.

27. Zahedi S. Energy efficiency: importance of indigenous microorganisms contained in the municipal solid wastes. Waste Manag. 2018;78:763-9.

28. Wang Q, Jiang G, Ye L, Yuan Z. Enhancing methane production from waste activated sludge using combined free nitrous acid and heat pretreatment. Water Res. 2014;63:71-80. 
29. Zhang T, Wang Q, Ye L, Yuan Z. Effect of free nitrous acid pre-treatment on primary sludge biodegradability and its implications. Chem Eng J. 2016;290:31-6

30. Erden $\mathrm{G}$, Filibeli A. Improving anaerobic biodegradability of biological sludges by Fenton pre-treatment: effects on single stage and two-stage anaerobic digestion. Desalination. 2010;251:58-63.

31. Pilli S, More TT, Yan S, Tyagi RD, Surampalli RY. Fenton pre-treatment of secondary sludge to enhance anaerobic digestion: energy balance and greenhouse gas emissions. Chem Eng J. 2016;283:285-92.

32. Apha A. Standard methods for the examination of water and wastewater. Washington: American Public Health Association; 2012.

33. Lowry OH, Rosebrough NJ, Farr AL, Randall RJ. Protein measurement with the Folin phenol reagent. J Biol Chem. 1951;193:265-75.

34. Peterson GL. A simplification of the protein assay method of Lowry et al. which is more generally applicable. Anal Biochem. 1977;83:346-56.

35. Dubois M, Gilles KA, Hamilton JK, Rebers PA, Smith F. Colorimetric method for determination of sugars and related substances. Anal Chem. 1956;28:350-6.

36. Yang L, Huang Y, Zhao M, Huang Z, Miao H, Xu Z, et al. Enhancing biogas generation performance from food wastes by high-solids thermophilic anaerobic digestion: effect of pH adjustment. Int Biodeterior Biodegrad. 2015;105:153-9.

37. Li X, Zhao J, Wang D, Yang Q, Xu Q, Deng Y, et al. An efficient and green pretreatment to stimulate short-chain fatty acids production from waste activated sludge anaerobic fermentation using free nitrous acid. Chemosphere. 2016;144:160-7.

38. Walker M, Zhang Y, Heaven S, Banks C. Potential errors in the quantitative evaluation of biogas production in anaerobic digestion processes. Bioresour Technol. 2009;100:6339-46.

39. Anthonisen AC, Loehr RC, Prakasam TB, Srinath EG. Inhibition of nitrification by ammonia and nitrous acid. J Water Pollut Control Fed 1976;48:835-52.

40. Wang $Q$, Ye L, Jiang G, Yuan Z. A free nitrous acid (FNA)-based technology for reducing sludge production. Water Res. 2013;47(11):3663-72.

41. Wang Q, Wei W, Gong Y, Yu Q, Li Q, Sun J, et al. Technologies for reducing sludge production in wastewater treatment plants: state of the art. Sci Total Environ. 2017; 587-588:510-21.

42. Wu QL, Guo WQ, Bao X, Zheng HS, Yin RL, Feng XC, et al. Enhanced volatile fatty acid production from excess sludge by combined free nitrous acid and rhamnolipid treatment. Bioresour Technol. 2017;224:727-32.

43. Pham TTH, Brar SK, Tyagi RD, Surampalli RY. Optimization of Fenton oxidation pre-treatment for $B$. thuringiensis-based production of value added products from wastewater sludge. J Environ Manage. 2010;91:1657-64.

44. Boulanger A, Pinet E, Bouix M, Bouchez T, Mansour AA. Effect of inoculum to substrate ratio (I/S) on municipal solid waste anaerobic degradation kinetics and potential. Waste Manag. 2012;32:2258-65.
Ready to submit your research? Choose BMC and benefit from:

- fast, convenient online submission

- thorough peer review by experienced researchers in your field

- rapid publication on acceptance

- support for research data, including large and complex data types

- gold Open Access which fosters wider collaboration and increased citations

- maximum visibility for your research: over $100 \mathrm{M}$ website views per year

At $\mathrm{BMC}$, research is always in progress.

Learn more biomedcentral.com/submissions 